\title{
Response of different Bt cotton (Gossypium hirsutum L.) hybrids to canopy modification practices
}

\author{
Amit Kaul*, J. S. Deol and A. S. Brar \\ Department of Agronomy, Punjab Agricultural University, Ludhiana -141004 (Punjab), INDIA \\ *Corresponding author. E-mail: amitkaul@ @au.edu
}

Received: July 18, 2015; Revised received: April 19, 2016; Accepted: July 09, 2016

\begin{abstract}
A field investigation was carried out to characterize the growth and development of $B t$ cotton hybrids by detopping and use of plant growth retardants during the rainy (kharif) season of 2011 and 2012. The experimental site had loamy sand soils with normal in reaction. The experiment (split plot) involved three Bt cotton hybrids (MRC 7017, MRC 7031 and RCH 314) in main plots and growth regulation treatments (Mepiquat chloride (MC) @ 300 ppm, 2, 3, 5-tri iodo benzoic acid (TIBA) @ 100 ppm and Maelic hydrazide (MH) @ 250 ppm) in sub plots with four replications. Hybrid MRC 7017 produced significantly higher $(p<0.01)$ seed cotton yield which was attributed to the maximum number of sympodial branches plant ${ }^{-1}$, total number of flowers and picked bolls plant ${ }^{-1}$. Application of MC @ 300 ppm, TIBA @ 100 ppm and MH @ 250 ppm reduced plant height, leaf area index and total dry matter accumulation than control. Detopping treatment significantly $(p<0.01)$ reduced plant height than control but attained more plant height than all the PGRs. MC @ 300 ppm, TIBA @ 100 ppm and MH @ 250 ppm at 80 days after sowing had beneficial effect on seed cotton yield. Detopping done at 80 days after sowing failed to influence the seed cotton yield during both the years. The results revealed that foliar application of MC @ 300 ppm yielded more seed cotton by improving the setting percentage and therefore, increased number of picked (open) bolls plant ${ }^{-1}$ without exhibiting any adverse effect on quality traits.
\end{abstract}

Keywords: Bt cotton hybrids, Maleic hydrazide (MH), Mepiquat chloride (MC), Plant growth regulators, Seed cotton yield, 2,3,5-tri iodo benzoic acid (TIBA)

\section{INTRODUCTION}

Productivity of cotton largely depends upon the availability of high yielding varieties and hybrids along with improved agronomic production technologies. Under optimum growing conditions, cotton crop produces excess vegetative biomass that is often associated with reduced yield (Heitholt 1994). Vigorous crop growth can be very frequent in mid to late season stages of crop development. A dense and lavish growth causes abnormal shedding of young fruiting bodies like buds, flowers and bolls, delayed maturity, boll rot (due to shading), and reduced yield (Zhao and Oosterhuis 2000). The plant therefore must have a balance between vegetative and reproductive growth for adequate carbohydrate supply for fruit development, and not excessive vegetative growth that inhibits fruit development (Kerby et al., 1997). Managing the equilibrium between vegetative and reproductive growth is an important part in cotton production. Plant growth can be modified by detopping and the use of plant growth regulators (PGRs) which may help in improving the cotton productivity. Applying PGRs to modify early and midseason growth is similar to other management practices. The key to modify plant growth is to know what the plant needs at each stage of development to reach the final goal of higher yield and quality. The next step is to do everything possible to provide for those needs. Growth retardants like mepiquat chloride (MC) and 2, 3, 5-tri iodo benzoic acid (TIBA) are known to reduce internodal length, thereby, reducing plant height and stimulating the translocation of photosynthates towards reproductive sinks (bolls), all of which result in higher yields (Kumar et al., 2005).

Removing the terminal main stem bud (detopping) is considered as an adjustment in cotton plants to modify the architecture of plant grown on irrigated fertile soils. Hallikeri et al., (2010) reported that detopping, decrease plant height and number of sympodial branches plant ${ }^{-1}$ but has a non-significant effect on boll weight and percent lint. However, the increase in seed cotton yield by detopping over no detopping was reported by Shwetha et al., (2009). Therefore, the objective of this study was to characterize the growth and development of $B t$ cotton hybrids by detopping and use of plant growth retardants for improving cotton productivity.

\section{MATERIALS AND METHODS}

Experimental site: The experiment was carried out at Punjab Agricultural University, Ludhiana, during kharif season of 2011 and 2012. The experimental site is situated at $30^{\circ} 54^{\prime} \mathrm{N}$ and $75^{\circ} 48^{\prime} \mathrm{E}$ at 247 meters 
above mean sea level. This region is characterized with subtropical, semiarid climate having three distinct seasons i.e. hot and dry summers (April-June), hot and humid monsoon (July-September) and cold winters (November-January). Considerable fluctuations are displayed by mean maximum and mean minimum temperatures during these seasons. Mean maximum temperature often reaches as high as $47^{\circ} \mathrm{C}$ in the month of June, while freezing temperatures accompanied by frosty spells are quite common during the months of December and January. Average rainfall ranges from 500$750 \mathrm{~mm}$, most of which is received during the monsoon period, the grand growth period of cotton crop. Some rainfall is also expected during winter months.

Weather: The meteorological data recorded at meteorological observatory of the Punjab Agricultural University, Ludhiana during the two crop seasons has been presented in fig. 1. The mean monthly relative humidity during crop seasons ranged from 44.7 to 82.7 per cent in 2011 and 31.8 to 77.0 per cent in 2012. Mean monthly maximum temperatures of $39.4^{\circ} \mathrm{C}$ and $39.6^{\circ}$ $\mathrm{C}$ were recorded in the month of May in 2011 and 2012, respectively. Total rainfall received during the cotton crop growing seasons of 2011 and 2012 was $1192.4 \mathrm{~mm}$ and $385.1 \mathrm{~mm}$, respectively, exhibiting enormous variation in distribution pattern and total rainfall received during the two years. The weather during 2011 was not favourable for the proper growth and development of cotton crop though it was favourable for the year 2012. The months of August and September experienced more than normal rainfall, the deviation being $333.7 \mathrm{~mm}$ and $75.3 \mathrm{~mm}$, respectively for the year 2011. However, the total rainfall received in the month of August was $513.4 \mathrm{~mm}$. All the hybrids on an average yielded less in the year 2011 than in the year 2012 because of higher rainfall received that caused shedding of fruiting structures and resulted in less flower and boll production during the year 2011 and more rainfall than normal also resulted in favourable conditions for pest buildup.

Soil of Experimental site: Representative samples of soil upto a depth of $0-15 \mathrm{~cm}$ and $15-30 \mathrm{~cm}$ from the experimental field were randomly collected from five places before sowing to determine the physicochemical properties of the soil. The soil was loamy sand with normal in reaction and for content of soluble salts. The organic carbon (Walkley and Black's, 1934), available nitrogen (Subbiah and Asija, 1956), available phosphorus (Olsen et al., 1954) and available potassium (Jackson, 1967) was 0.31\%, 258.5, 24.4 and $339.4 \mathrm{~kg} \mathrm{ha}^{-1}$, respectively.

Experimental treatments: The treatments comprised of different hybrids and canopy modification practices. The experiment used a split plot design with four replicates in which $B t$ cotton hybrids were randomized on main plots, plant growth regulation treatments were randomized on sub plots (Table-1). The experiment was re-randomized each year. In both years, three $B t$ II genotypes were selected (MRC 7017, MRC 7031 and $\mathrm{RCH} 314$ ), which were prevalent and recommended in Punjab, India during these years and also have different growth habits. RCH 314 is short and having less sympodial branches as compared to MRC 7017 and MRC 7031. $B t$ cotton hybrids were sown on May 13 during 2011 and on May 11 during 2012. Sowing was done with a uniform seed rate of $1.875 \mathrm{~kg} \mathrm{ha}^{-1}$ by dibbling two seeds per hill and keeping row to row and plant to plant spacing of $67.5 \mathrm{~cm}$ and $75 \mathrm{~cm}$, respectively. Gap filling was done 25 days after sowing to maintain 100 per cent crop stand. Whereas, thinning of seedlings was done after first irrigation keeping one plant hill ${ }^{-1}$. Flood irrigation was applied as needed each year in order to avoid limiting plant response from the treatments. All other crop inputs including pest, weed, disease control, nitrogen, potassium, phosphate and sulphur fertilizers were based on the standard practices recommended by Punjab Agricultural University, Ludhiana (Anonymous, 2011a and 2012b). Five plants in each plot was separately tagged for the measurement of plant height, leaf area index, main stem internodes, monopodial branches plant ${ }^{-1}$, sympodial branches plant ${ }^{-1}$, total number of flowers plant ${ }^{-1}$, unopenend bolls plant ${ }^{-1}$ and the number of picked bolls plant ${ }^{-1}$ of each tagging harvested plot $^{-1}$ were recorded. For calculating dry matter accumulation by cotton plants, three plants were randomly selected from each plot and were uprooted. The plants were then separated into stem, leaves and fruiting bodies. The plant parts were first dried in the sun and then in an oven at $60^{\circ} \mathrm{C}$ till constant weight. Dried samples were weighed and weight was expressed in gram plant ${ }^{-1}$. Setting percentage denotes that out of total flowers formed, how many were eventually set into bolls. This was calculated by dividing total number of bolls plant ${ }^{-1}$ with total number of flowers plant ${ }^{-1}$ from tagged plants and multiplied by hundred. Bolls from each tagging of each plot were ginned in individual groups. Boll mass was determined by dividing the weight of seed cotton by number of bolls harvested. Open bolls were hand harvested thrice each year and the total number of bolls picked in each harvest was recorded. Lint yield was determined from ginned seed cotton.

Quality Parameters were also determined which influenced by the plant growth regulation and the bartlett index was calculated with the help of all the three pickings and it was worked out by following formula as given by Bartlett (1973).

Where, $\mathrm{P}_{1}=$ seed cotton yield in the first picking, $\mathrm{P}_{2}=$

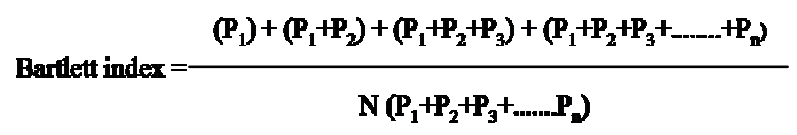

seed cotton yield in the second picking, $\mathrm{P}_{3}=$ seed cotton yield in the third picking and $\mathrm{N}=$ number of pickings. 
Seed index was calculated by the weight of 100 seeds in each treatment was recorded as seed weight. Ginning outturn was calculated as weight of lint divided by the weight of seed cotton and multiplied with hundred. Lint index was determined on the basis of following formula.

$$
\text { Lint index }=\frac{\text { Ginning outturn }}{100 \text { - Ginning outturn }} X \text { Seed index }
$$

Statistical analysis: The various data were statistically analyzed by general linear model (GLM) procedure (SAS Software 9.3, SAS Institute Ltd., U.S.A.) as per the standard procedure given by Gomez and Gomez (1984) for the analysis of variance (ANOVA) for split plot design for both years. All possible pairs of treatment means were compared with Duncan's multiple range test (DMRT) at $5 \%$ probability level.

\section{RESULTS AND DISCUSSION}

Effect of hybrids and plant growth regulation on growth parameters of cotton: During the present study, plant height of cotton was recorded significantly higher in hybrid MRC 7017 (125.7 and $138.3 \mathrm{~cm}$ ) which was statistically at par with hybrid MRC 7031 $(125.2$ and $137.8 \mathrm{~cm})$ during 2011 and 2012 respectively (Table-2). Plant height is a genetically controlled character and the ultimate height of the crop or a particular variety is dependent upon its genetic makeup. The results obtained by Srinivasulu et al., (2006) also emphasize the same point and they observed a significant difference in different cotton hybrids and concluded that the plant height of MECH $12 \mathrm{Bt}$ and MECH $184 B t$ hybrids was markedly lower than the other hybrids (VCH 225, NSPHH 8 and PRCHH 5). Singh et al (2011) also reported that the growth habit of three $B t$ cotton hybrids MRC 7361, Bioseed 6488 and $\mathrm{RCH} 134$ was differed for plant height and other growth attributes. Different plant growth regulation treatments had a significant effect on plant height of cotton during both the years (2011 \& 2012) of investi-

Table 1. Details of experimental treatments

\begin{tabular}{lcc}
\hline Treatment & $\begin{array}{c}\text { Concen- } \\
\text { tration } \\
\text { (ppm) }\end{array}$ & $\begin{array}{c}\text { Time of } \\
\text { application }\end{array}$ \\
\hline Main plots & & \\
Hybrids - 3 & - & - \\
MRC 7017 & - & - \\
MRC 7031 & - & - \\
RCH 314 & & \\
Sub Plots & - & - \\
Plant growth regulation - 5 & - & 80 DAS* \\
Control & 300 & do \\
Detopping & 100 & do \\
Mepiquat chloride (MC) & & do \\
2,3,5-tri iodo benzoic acid & (TIBA) & \\
Maleic hydrazide (MH) & 250 & \\
\hline DAS* = Days after sowing & &
\end{tabular}

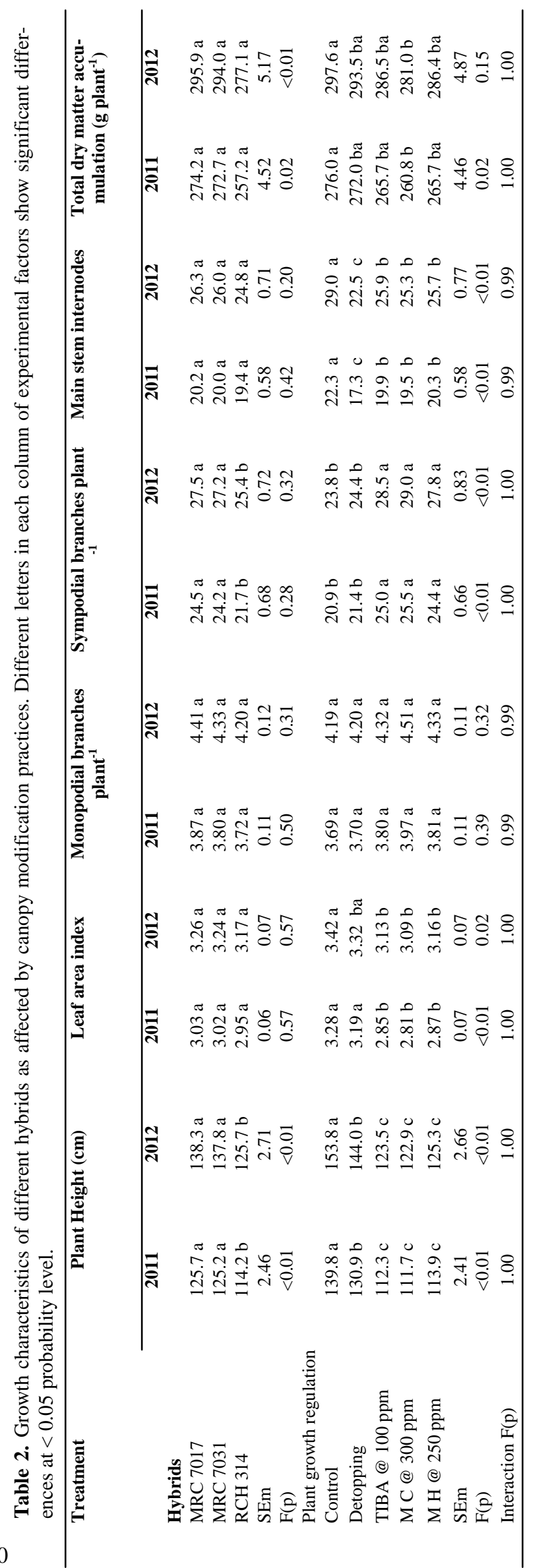


Amit Kaul et al. / J. Appl. \& Nat. Sci. 8 (3): 1188 - 1197 (2016)

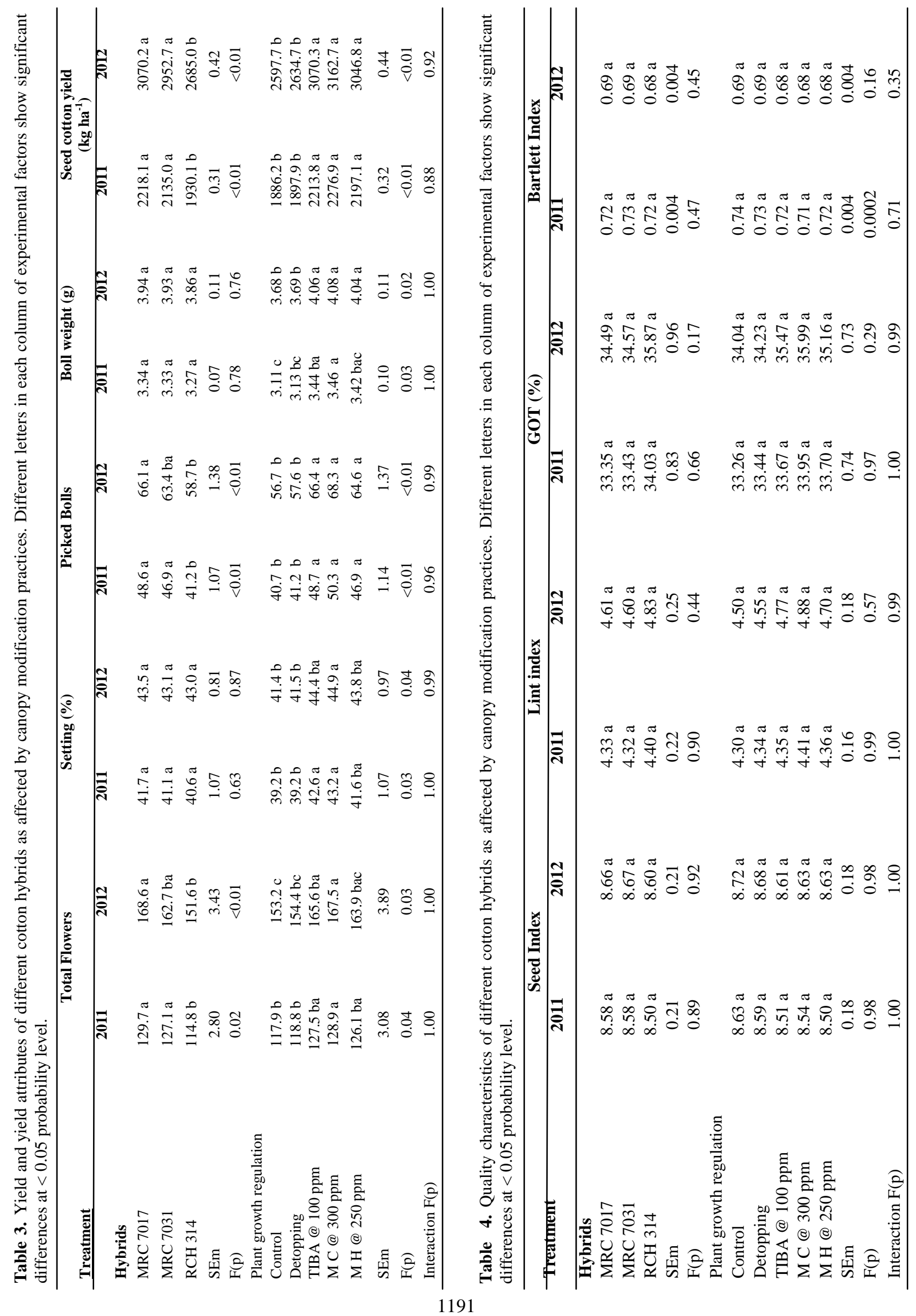


Amit Kaul et al. / J. Appl. \& Nat. Sci. 8 (3): 1188 - 1197 (2016)
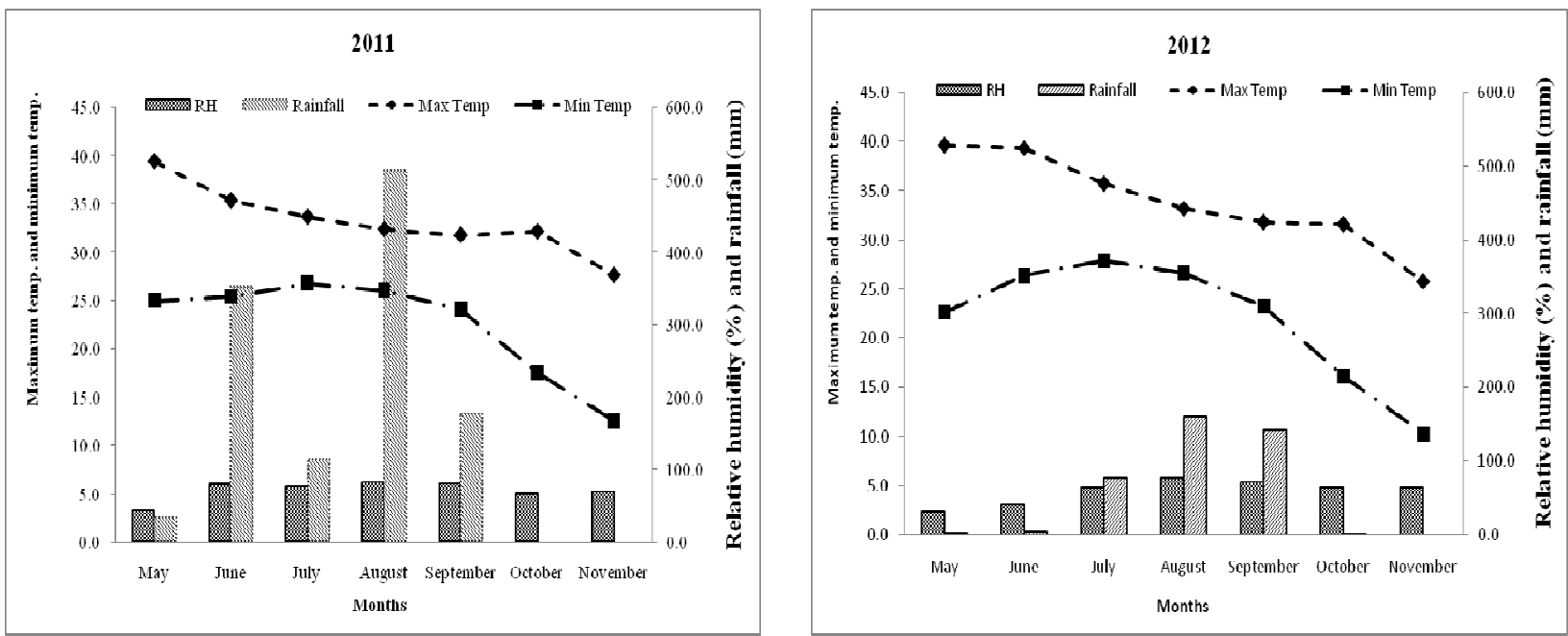

Fig. 1. Mean monthly meteorological data during the crop seasons of 2011 and 2012.
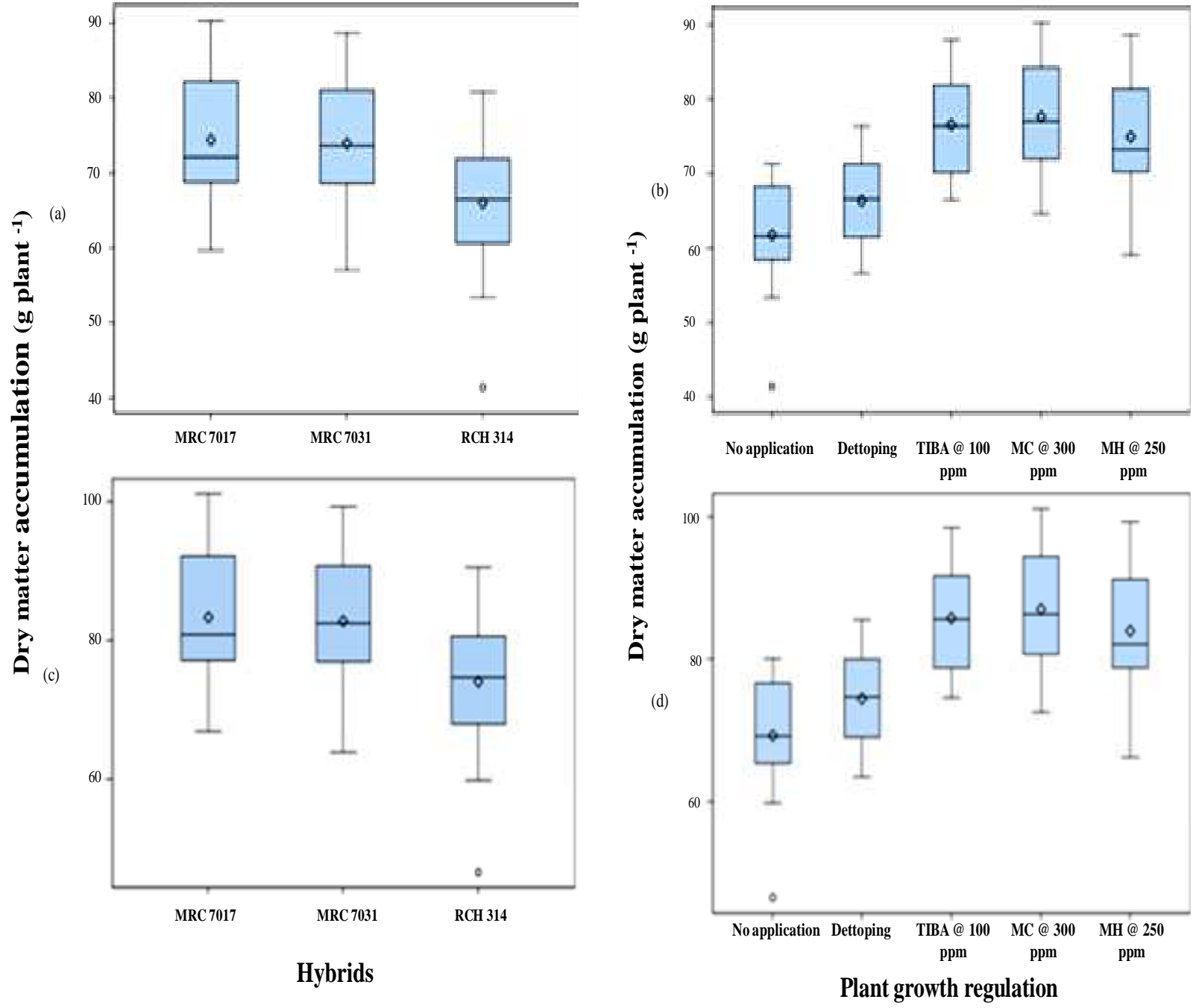

Fig. 2. Dry matter accumulation in fruiting bodies of Bt cotton hybrids as affected by plant growth regulation treatments during 2011 ( $a$ and $b$ ) and 2012 ( $c$ and d).

gation however; the response varied with the plant growth regulator (PGR) and its concentration (Table2). The foliar application of MC @ 300 ppm resulted in minimum plant height which was significantly shorter by $20.1 \%$ than no application and $6.36 \%$ than detopping during both the years of study. Though, 
TIBA@100 ppm and MH @ 250 ppm do not indicate a rank growth with MC @ 300 ppm but had smaller plants than no application and detopping, during both the years. These results were in agreement with Halmann (1990) who reported that MC caused more compact growth of cotton plant by checking the apical dominance by acting as anti-gibberellin (by blocking the gibberellin biosynthesis). Siebert and Stewart (2006) also reported that application of MC resulted in shorter and more compact plants of cotton. Detopping also reduced the height of cotton plants by $6.4 \%$ than control but did not able to produce shorter plants than $\mathrm{MC}, \mathrm{MH}$ and TIBA during both the years of study (Table-2). Shorter plants in cotton was also reported by the application of $\mathrm{MH}$ and TIBA which were discussed by Djanaguiraman et al., (2005) that TIBA inhibits the concentration of auxin at the axillary bud and resulted in reduced supply of auxin in the region of axillary and thereby relieves the bud inhibition which caused reduced stem elongation. Whereas, $\mathrm{MH}$ act as an antimitotic agent when applied to plants, it moves through the cuticle and is actively transported to tissues where cell division is occurring which results in reduced internodal length and plant growth.

Dry matter accumulation (DMA) and its partitioning is one of the most important parameter and have a marked influence on final yield realization of a crop. The optimum accumulation of dry matter followed by adequate partitioning of assimilates to the developing sinks enables the crop to attain its true yield potential. Total dry matter accumulation (TDMA) for all the hybrids showed a non significant difference except for the fruiting bodies at harvest (Table-2). Different hybrids (MRC 7017, MRC 7031 and RCH 314) varied significantly for the accumulation of dry matter into fruiting bodies with the maximum dry weight of 74.4 and 83.4 g plant $^{-1}$ for hybrid MRC 7017 during 2011 and 2012, respectively as compared with other two hybrids (Fig. 2). On an average hybrid MRC 7017 and MRC 7031 recorded $12.7 \%$ and $11.9 \%$ higher dry weight of fruiting bodies as compared to hybrid $\mathrm{RCH}$ 314 during 2011 and 2012, respectively. These results also confirm the findings of Heitholt et al., (1992) who observed that the genetic build up primarily governs the amount of fruiting bodies formed by the crop and number of fruits attained by the plants of a particular hybrid. Growth regulation treatments had a significant influence on TDMA during both the years (Table-2). Application of MC @ 300 ppm significantly reduced TDMA by $5.51 \%$ and $5.67 \%$ than no application during 2011 and 2012, respectively. However, all other canopy modification practices resulted statistically similar results for the TDMA with MC @ 300 ppm. Although, all the plant growth regulators resulted in partitioning of significantly more dry matter into the fruiting bodies and less of it towards the vegetative parts in both the years as compared to control and de- topping (Table-2 and Fig. 1). TDMA was reduced by application of growth retardants might be due to the inhibitory effect on vegetative growth and leaf area of the cotton plant. MC, TIBA and MH application exerted a significant influence on partitioning of dry matter into fruiting bodies of cotton as it resulted in significantly less dry matter allocation towards vegetative plant parts but more of it towards the fruiting bodies. These data are consistent with Nuti et al., (2000), who applied MC to control vegetative growth in cotton, MC caused a shift in partitioning of photo-assimilates from vegetative to reproductive growth. The magical properties of MH have also been observed by (Rahman et $a l ., 2004)$ that the reduction in plant height of cotton attribute more assimilates to the fruiting bodies rather than the vegetative parts.

Leaf area index (LAI) is an important parameter of plant growth which directly influences interception of solar radiation by the canopy, photosynthesis and ultimately the yield of a crop. Hybrids did not vary significantly for LAI during both the years. However, the application of TIBA @ 100 ppm and MH @ 250 ppm reduced the LAI, but with the greatest relative reduction of LAI in MC @ 300 ppm as compared to control and detopping during 2011 (Table-2). The per cent reduction of LAI in MC, TIBA and $\mathrm{MH}$ was $14.3 \%$, $13.1 \%$ and $12.5 \%$ respectively, during 2011 . However, the reduction was $9.64 \%, 8.47 \%$ and $7.60 \%$ during 2012. Reduction in LAI with application of MC in cotton was also reported by Pettigrew and Johnson (2005); and Gwathmey and Clement (2010).

Hybrids MRC 7017, MRC 7031 and RCH 314 did not show any variation for the main stem internodes (MSI) during both the years of study. Whereas, after the application of PGR's and detopping (80 DAS) the main stem internode number was significantly reduced in detopping (17.3 and 22.5) followed by MC (19.5 and 25.3), TIBA (19.9 and 25.9) and MH (20.3 and 25.7) than control during 2011 and 2012, respectively. The main stem internode number for all the PGR's reduced significantly than control but their relative number of main stem internodes stood statistically similar. The decrease in number of main stem internodes in plant growth regulator treatments as compared to control might be due to the anti gibberellin nature of $\mathrm{MC}$, auxin polar transport inhibitor nature of TIBA and antimitotic activity of $\mathrm{MH}$ as evident by shorter plant height of cotton. Jonathan and Alexander (2006) also reported that application of $\mathrm{MC}$ reduced the number of main stem internodes in cotton.

Monopodial branches are the vegetative branches which arise from the lower nodes of the plant. As evident from data presented in table-2, hybrids did not differ significantly for the number of monopodial branches plant ${ }^{-1}$. These three hybrids have same morphological behaviour to produce monopodial branches which was attributed to their similar genetic make up. 
Heitholt et al., (1992) and Brar (1997) also confirmed that similar genetic make up of cotton hybrids resulted in almost same growth pattern of the plant. Plant growth regulation treatments failed to influence the number of monopodial branches plant ${ }^{-1}$ significantly in any of the two years because PGR's were applied either at maximum vegetative growth stage or thereafter, whereas the monopodial branches arise from the lower nodes of the plant during the earlier stages of crop growth (Table-2). The findings of Rajni (2010) also confirmed that the application of PGR's in cotton did not affect the monopodial branches.

Effect of hybrids and plant growth regulation on yield attributes of cotton: A varietal difference for flower distribution was observed at different fruiting positions in cotton plants (Table-3). Numbers of fruiting sites occupied by flowers were significantly higher in hybrid MRC 7017 (129.7 and 168.6) as compared to RCH 314 (114.8 and 151.6) but it was statistically at par with hybrid MRC 7031 (127.1 and 162.7) during 2011 and 2012, respectively. The differential ability of cultivars to produce flowers has also been reported by Heitholt et al., (1992). Hybrids MRC 7017 and MRC 7031 also attained more number of picked bolls plant ${ }^{-1}$ during both the years of study and it was might be due to the fact that more number of sympodial branches plant $^{-1}$ and flowers plant ${ }^{-1}$ upshots $17.9 \%$ and $13.8 \%$ pickable bolls in MRC 7017 and MRC 7031 than RCH 314, respectively, during 2011 while during 2012 the per cent increase was 12.6 and 8.01, respectively. The variation in number of flowers produced plant ${ }^{-1}$ can be explained by the differences in genetic makeup of the plants and their capacity to produce more number of sympodial branches plant $^{-1}$ which resulted in more fruiting points plant $^{-1}$ (Table-3).

The influence of PGR's on total number of flowers and pickable bolls was significantly depicted in table-3. The foliar application of MC @ 300 ppm had increased the percentage of fruiting sites occupied by bolls (boll set) and boll load plant ${ }^{-1}$. Moreover, MC application contributed $23.5 \%$ and $20.4 \%$ more pickable bolls than the control treatment and $22.1 \%$ and $18.6 \%$ more pickable bolls than in the detopping treatment during 2011 and 2012, respectively. All the PGR treatments were statistically at par with each other along with significantly higher number of flowers and picked bolls plant ${ }^{-1}$ than control and detopping. The gain in boll set along with higher fruit set plant ${ }^{-1}$, sharply increment in boll load plant ${ }^{-1}$ carried to harvest. The increase in number of picked bolls plant ${ }^{-1}$ with foliar application of MC was due to the improved setting percentage. The significant improvement in the setting percentage with MC application might be due to better partitioning of metabolites towards the fruiting bodies due to growth retardation by MC (Wallace et al., 1993) thereby exerting a favorable effect on retention of fruiting bodies by preventing their shedding.
Gormus (2006) also reported that MC decreased the vegetative growth of cotton plant and in-turn reproductive growth was enhanced by shifting assimilates towards the fruiting points. The decrease in number of picked bolls plant ${ }^{-1}$ with detopping was due to decrease in number of sympodial branches plant ${ }^{-1}$ and reduced setting percentage, which might be due to less suppression of branch primordia and retardation of vegetative growth, thereby lowering the mobilization of photosynthates into fruiting bodies and retention of fruiting bodies (Owen and Craig 2003). MH and TIBA application also suppressed plant height of cotton which helped in initiation of more lateral branches and improving the mobilization of assimilates into fruiting bodies as evident from higher number of picked bolls plant $^{-1}$. Djanaguiraman et al., (2005) reported an increase in number of flowers and bolls in cotton when TIBA was applied as compared to control.

Different hybrids did not vary significantly for boll weight during both the years (Table-3). The average boll weight was significantly influenced by foliar spray of MC @ 300 ppm and the treated plants had heavier bolls than untreated control which exhibited $11.3 \%$ and $10.9 \%$ greater boll weight than control during 2011 and 2012, respectively. Furthermore, MC @ 300 ppm, TIBA@ 100 ppm and MH @ 250 ppm were statistically at par with each other in both the years while, TIBA @ 100 ppm and MH @ 250 ppm were numerically equal with detopping during 2011 and attained significantly higher boll weight than control (Table-3). However, during 2012 TIBA @ 100 ppm and MH @ $250 \mathrm{ppm}$ attained significantly higher boll weight than both detopping and control (Table-3). Higher boll weight with MC application was because of improved source-sink relationship and better translocation of metabolites towards reproductive sinks (fruiting bodies) due to retardation of excessive vegetative growth Siddique et al., (2002). TIBA and MH also reduced the vegetative growth of cotton plant which helped in better translocation of assimilates towards the bolls. Brar et al., (2000) and Kumar et al., (2006) had also reported a significant increase in boll weight of cotton with MC application.

Effect of hybrids and plant growth regulation on seed cotton yield of cotton: Yield is the ultimate result of the interaction of various factors and is a valid criterion for comparing the efficiency of different treatments. Hybrids MRC 7017, MRC 7031 and RCH 314 differed significantly with each other for the seed cotton yield during both the years (Table-3). During first year hybrid MRC 7017 and MRC 7031 resulted in $14.9 \%$ and $10.6 \%$ higher total seed cotton yield as compared to RCH 314, respectively. However, during the second year the respective increase was $14.3 \%$ and $9.97 \%$. The results of Blaise et al., (2003) also confirmed that $B t$ hybrids differed significantly for seed cotton yield. Higher yield by the hybrid MRC 7017 
can be explained by the better growth and development due to its higher genetic potential as evident from the better plant height which resulted in increased number of sympodial branches plant ${ }^{-1}$, flowers plant ${ }^{-1}$ and picked bolls plant ${ }^{-1}$ as recorded by the hybrid MRC 7017 .

The perusal of data (Table-3) showed that the foliar application of MC @ 300 ppm improved the seed cotton yield as it exerted a favourable effect on various physiological processes leading to improvement in yield attributing characters like open bolls plant ${ }^{-1}$ during 2011 and 2012 and, hence increased the yield. MC @ 300 ppm application significantly help in enhancing the seed cotton yield over control and detopping but it was statistically at par with that obtained with TIBA @ 100 and $\mathrm{MH} @ 250$ ppm application. Foliar application of MC@300 ppm, TIBA @ 100 and MH @ 250 ppm resulted in $20.7 \%, 17.4 \%$, and $16.5 \%$ higher seed cotton yield than control, respectively during 2011. The corresponding increase in seed cotton yield during 2012 was $21.7 \%, 18.2 \%$, and $17.3 \%$. The significant increase in seed cotton yield with MC application over the untreated control might be due to the restricted vegetative growth and thus enhance reproductive organs by allowing plants to direct more energy towards the reproductive structure (Sawan et al., 2009). Zhao and Oosterhuis (1999) also reported that MC application improved leaf photosynthetic rate and increased lint yield. Detopping treatment did not perform better and was statistically at par with untreated control during both the years of experimentation. The percentage of total yield reduction in detopping during 2011 and 2012 was $19.9 \%$ and $20.0 \%$, respectively in comparison with MC application. A non significant influence on seed cotton yield and lint yield per hectare was observed by Siddique et al., (2002) by detopping plants at 90 DAS. It was also observed that detopping in $G$ hirsutum was not advantageous in terms of seed cotton yield Turkhede et al., (2003). The interaction between cotton hybrids and plant growth regulation treatments were found to be non significant during both the years of study.

The mean grain yield during 2011 was significantly (by $t$ test at $5 \%$ level of probability) lower by $38.6 \%$ than that obtained during 2012, owing to unfavourable weather conditions during 2011. The data in table-3 revealed that during 2011 average number of flowers plant $^{-1}$ were less by $23.1 \%$ than 2012 . It might be due to more number of cloudy days during the month of August and September as represented in fig 1, the time when fruiting structures are developing which resulted in shedding of flowers. Pettigrew et al., (1992) and Heitholt (1993) also reported that unfavourable weather conditions during maximum growth stage resulted in lesser yields in cotton.

Effect of hybrids and GR's on quality parameters: Different hybrids and growth regulator treatments did not exert any significant influence on the quality parameters viz bartlett index, ginning outturn, seed index and lint index in any of the two years of experiment as evident from table-4. Mert and Caliskan (1998) and Iqbal et al., (2004) also reported that growth regulators do not have any effect on the ratio of lint to seed. Athayde and Lamas (1999) and Ghourab et al., (2000) also reported that percentage fibre was not affected by application of PGRs.

\section{Conclusion}

The results of the present investigation revealed that the hybrid MRC 7017 and MRC 7031 had better crop canopy with $9.6 \%$ and $10.1 \%$ taller plant than $\mathrm{RCH}$ 314 , respectively during both the years of study. Hybrid MRC 7017 and MRC 7031 also produced more seed cotton yield than the hybrid $\mathrm{RCH} 314$, which attributed to more number of sympodial branches plant ${ }^{-1}$, flowers and picked bolls plant ${ }^{-1}$. The study also suggests that mepiquat chloride (MC) @ 300 ppm applied at 80 days after sowing (at maximum growth stage of cotton) reduce height more effectively as compared to the detopping and control. The reduced plant height resulting from application of MC @ 300 ppm significantly translated into advantages in yield. Although, yield response to $\mathrm{MC} @ 300$ ppm was maximum among all the treatments but was statistically at par with 2, 3, 5-tri iodo benzoic acid (TIBA @ 100 ppm) and maleic hydrazide (MH @ 250 ppm). Findings support the hypothesis that plant growth regulators exhibit shorter internodes with compact plants which benefits more boll set percentage and yield formation in all the three cotton hybrids by reducing LAI. Increase in stem starch reserves as evident from higher dry matter of fruiting bodies with plant growth regulators may have been due to the alteration of source sink towards reproductive sinks (bolls). Thus, PGR chemicals could become a useful tool in the cotton producers reserve to ensure efficient production.

\section{ACKNOWLEDGEMENTS}

The authors are thankful to the Punjab Agricultural University, Ludhiana for providing funds and facility for field and laboratory work. Authors are thankful for the comments and suggestion given by anonymous reviewers for the improvement of the manuscript.

\section{REFERENCES}

Anonymous (2011a). Package of Practices for Crops of Punjab (Kharif). pp 35-57. Punjab Agricultural University, Ludhiana.

Anonymous (2012b). Package of Practices for Crops of Punjab (Kharif). pp 35-57. Punjab Agricultural University, Ludhiana.

Athayde, M. L. F. and Lamas, F. M. (1999). Sequential applications of mepiquat chloride in cotton plants. Pesquisa Agropecuaria Brasileira. 34: 369-375.

Bartlett, M. S. (1973).Some examples of statistical methods of research in agriculture and applied botany. Inter. $J$. Royal Stat. Soc. B. 4: 37-70. 
Blaise, J. S., Rao, M. R. K., Mayee, C. D. and Deshmukh, M. S. (2003). Assessment of agronomic efficiency of $B t$ cotton (Gossypium hirsutum L.) in rainfed vertisols. $J$. Indian Soc. Cotton Improv. 28: 185-190.

Brar, Z. S. (1997). Improving cotton yield through increased retention and opening of the bolls. Final Technical Report. ICAR, New Delhi. pp: 60.

Brar, Z. S., Singh, A. and Singh, T. (2000). Response of hybrid cotton (Gossypium hirsutum) to nitrogen and canopy modification practices. Indian J. Agron. 45: 395-400.

Djanaguiraman, M., Sheeba, J. A., Durga, devi, D. and Bangarusamy, U. (2005). Response of cotton to Atonik and TIBA for growth, enzymes and yield. J. Biol. Sci. 5: 158-162.

Ghourab, M. H. H., Wassel, O. M. M. and El-Nour, M. S. A. (2000). The effect of mepiquat chloride application on the productivity of cotton plants. Egyptian J. Agri. Res. 78: 1207-1218.

Gomez, K.A. and Gomez, A.A. (1984). Statistical Procedures for Agricultural Research, John Wiley and Sons, Inc, U K.

Gormus, O. (2006). Effect of mepiquat chloride and boron on irrigated cotton (Gossypium hirsutum) in Turkey. Indian J. Agron. 51: 149-151.

Gwathmey, C. O. and Clement, J. D. (2010). Alteration of cotton source-sink relations with plant population density and mepiquat chloride. Field Crops Res. 116: 101-107.

Hallikeri, S. S., Halemani, H. L., Patil, V. C., Palled, Y. B., Patil, B. C. and Katageri, I. S. (2010). Effect of nitrogen levels, split application of nitrogen and detopping on seed cotton yield and fibre quality in Bt cotton. Karnataka J. Agric. Sci. 23 (3): 418-422.

Halmann, M. (1990). Synthetic plant growth regulators. $A d v$. Agron. 43: 47-105.

Heitholt (1993). Cotton boll retention and its relationship to lint yield. Crop Sci. 33: 486-490.

Heitholt, J. J. (1994). Canopy characteristics associated with deficient and excessive cotton plant densities. Crop Sci. 34: 1291-1297.

Heitholt, J. J., Pettigrew, W. T. and Meredith, W. R. Jr. (1992). Light interception and lint yield of narrow row cotton. Crop Sci. 32: 728-733.

Iqbal, M., Iqbal, M. Z., Khan, R. S. A., Hayat, K. and Chang, M. A. (2004). Response of new cotton variety MHN700 to mepiquat chloride under varying plant population. Pakistan J. Biol. Sci.: 1898-1902.

Jackson, M. L. (1967). Soil chemical analysis. Asia publishing house New Delhi.

Jonathan, D. S. and Alexander, M. S. (2006). Influence of plant density on cotton response to mepiquat chloride application. Agron. J. 98: 1634-1639.

Kerby, T. A., Plant, R. E. and Horrocks, R. D. (1997). Height to node ratio as an index of early season cotton growth. J. Prod. Agric. 10: 80-83.

Kumar, K. A. K., Patil, B. C. and Chetti, M. B. (2005). Effect of plant growth regulators on physiological components of yield in hybrid cotton. Indian J. Plant Physiol. 10: 187-190.

Kumar, K. A. K., Ravi, V., Patil, B. C. and Chetti, M. B. (2006). Influence of plant growth regulators on morphophysiological traits and yield attributes in hybrid $B t$ cotton (DHH-11). Annals Bio. 22: 53-58.
Mert, M. and Caliskan, M. E. (1998). The effects of mepiquat chloride (PIX) on yield, yield components and fibre characteristics of cotton. Turkish J. Field Crops 3: 68-72.

Nuti, R. C., Witten, T. K., Jost, P. H., Cothern, J. T. (2000). Comparisons of Pix Plus and additional foliar Bacillus cereus in cotton. Proceedings Beltwide Cotton Conferences, San Antonio, TX, USA, 4-8 January, Memphis, USA; National Cotton Council. 684-687.

Olsen, S. R., Cole, C. F., Watanabe, F. S. and Dean, L. A. (1954). Estimation of available phosphorous by extraction with sodium bicarbonate. USDA Circ. 34: 1-19.

Owen, C. G. and Craig, C. C. (2003). Managing earliness in cotton with mepiquat type growth regulators. Plant Management Network, Research Report

Pettigrew, W. T. and Johnson, J.T., (2005). Effects of different seeding rates and plant growth regulators on earlyplanted cotton. J. Cotton Sci. 9: 189-198.

Pettigrew, W. T., Heitholt, J. J. and Meredith, W. R. (1992). Early season floral bud removal and cotton growth, yield and fibre quality. Agron. J. 84: 209-214.

Rahman, M. S., Tahar, N. I. M. A. and Karim, M. A. (2004). Influence of GA3 and $\mathrm{MH}$ and their time of spray on dry matter accumulation and growth attributes of soybean. Pakistan J. Biol. Sci. 7 (11): 1851-1857.

Rajni (2010). Growth regulation and defoliation studies in hybrid Bt cotton (Gossypium hirsutum L.). PhD. dissertation, Punjab Agricultural University, Ludhiana, India.

Sawan, Z. M., Fahmy, A. H. and Yousef, S. E. (2009). Direct and residual effects of nitrogen fertilization, foliar application of potassium and plant growth retardant on Egyptian cotton growth, seed yield, seed viability and seedling vigor. Acta Ecologica Sinica. 29: 116-123.

Shwetha, N. S., Halepyati, A. S. and Pujari, B. T. (2009). Effect of detopping, removal of monopodia and plant spacings on nutrient uptake, quality parameters and economics of Bt cotton (Gossypium hirsutum L.). Karnataka J. Agric. Sci. 22 (4): 892-893.

Siddique, M. R. B., Prasad, M. and Gautum, R. C. (2002). Response of cotton (Gossypium hirsutum L.) to mepiquat chloride and topping under varying levels of nitrogen. Indian J. Agron. 47: 550-555.

Siebert, J. D. and Stewart, A. M. (2006). Influence of plant density on cotton response to mepiquat chloride application. Agron. J. 98: 1634-1639.

Singh, K., Singh, H., Gumber, R. K. and Rathore, P. (2011). Studies on the Seed Cotton Yield, Growth and Yield Contributing Characters of New Bt Cotton Hybrids under Varied Agronomic Manipulations. World Cotton Research Conference on Technologies for Prosperity pp 338-340.

Srinivasulu, K., Hema, K., Prasad, N. V. V. S. D. and Rao, K. V. K. (2006). Performance of cotton hybrids under different spacing and nitrogen levels in black cotton soils of coastal Andhra Pradesh. J. Cotton Res. Dev. 20 (1): 99-101.

Subbiah, B. V. and Asija, G. L. (1956). A rapid procedure for the estimation of available nitrogen in soils. Current Sci. 25: 259-266.

Turkhede, A. B., Wankhade, S. T., Katkar, R. N. and Sakhare, B. A. (2003). Effect of detopping and foliar sprays of plant growth hormones and nutrients on growth and yield of rainfed cotton. J. Cotton Res. Dev. 17: 150-152. 
Amit Kaul et al. / J. Appl. \& Nat. Sci. 8 (3): 1188 - 1197 (2016)

Walkley, A., Black, C.A., (1934). An examination of the Detjareff method for determining soil organic matter and a proposed modification of the chromic acid titration method. Soil Sci. 37: 27-38.

Wallace, T. P., Snipes, C. E. and White, B. W. (1993). Effect of single and multiple applications of mepiquat chloride on Mississippi cotton. Research Report Mississippi Agricultural and Forestry Experiment Station. 18: pp 5.

Zhao, D. L. and Oosterhuis, D. M. (2000). Pix plus and me- piquat chloride effects on physiology, growth, and yield of field grown cotton. J. Plant Growth Regul. 19: 415422.

Zhao, D., Oosterhuis, D.M. (1999). Physiological, growth and yield responses of cotton to Mepplus and mepiquat chloride. Proceedings Beltwide Cotton Conferences, Orlando, Florida, USA, 3-7 January, Memphis, USA; National Cotton Council. 599-602. 